\author{
Yurii Zavatskyi, \\ PhD (Candidate of Psychological Sciences), \\ Head of the Department of Human Health and Physical Education, \\ Volodymyr Dahl East Ukrainian National University, \\ 59 A, Tsentralnyi Avenue, Severodonetsk, Ukraine
}

\title{
INFLUENCE OF SOCIO-PSYCHOLOGICAL FACTORS ON THE FORMATION OF SUBJECTIVE WELL-BEING OF A MARRIED PERSON
}

The paper is aimed at identifying the influence of socio-psychological factors on the formation of subjective wellbeing of a married person. The following methods were used: questionnaire, psychodiagnostic techniques for investigating satisfaction with marriage, personal self-fulfilment in the family (on the operational level and the level of values and role sets), socio-psychological adaptedness, conformity of family values and role expectations in marriage. The data about the content, structural components (cognitive and evaluational, value and motivational, emotional and behavioural) and functions (regulatory, prognostic, developmental) of subjective well-being of a married person have been presented. Socio-psychological factors of subjective well-being of a married person have been specified.

Keywords: personality, well-being, marriage, socio-psychological factors, subjective well-being.

\section{Introduction}

With drastic trasformational changes and reorganisation of all spheres of life that are taking place in contemporary socity, the relevance of socio-psychological research on the issue of personality's well-being is increasing $[2 ; 3]$. It is explained by the necessity to find the basis for maintaining internal equilibrium under such conditions, what components it is based on, its role in behavioural regulation and to distinguish methods of psychological aid in solving the problem of supporting personality's subjective well-being $[1 ; 5]$.

One of the most significant spheres of life is a family, where marital relations are central: they create psychological space of personal lifeworld, determine the quality of family life [4;6]. Marital well-being provides the feeling of personality's subjective satisfaction with marital realtions and is the basis for psychological comfort and positive psychoemational feeling, therefore, the issue of socio-psychological factors of subjective well-being in marriage is worth investiagting.

Over the last years, some aspects of personality's psychological well-being has become the subject of psychological research: the structure of personality's psychological well-being (E. Diner); the influence of life goals on subjective well-being (R. Emmons); gender differences in experiencing subjective well-being (R. Inglehart); peculiarities of subjective well-being and its relation to emotional intelligence (I. Horbal, M. Yeleiko); functions of personal aspirations in experiencing subjective wellbeing by a young person (H. Puchkova). As for the works investigating marital well-being, we can mention the ones devoted to psychological compatibility of a married couple and emotional adaptation during the first years of family life (M. Obozov, A. Sultanova, T. Trapeznikova, P. Yakobson, et al.); factors affecting satisfaction with marriage among men and women, the character of communication between them (Yu. Aloshina, L. Homzan,
O. Kaminska, N. Khloponina, et al.); the influence of value orientations and marital mindset of partners on intrafamilial interaction (V. Bocheliuk, T. Hovorun, H. Dubchak, L. Moroz, I. Khitrina et al.); identification of a personality in marriage as a condition for marital well-being (Yu. Dmytruk); the process of building marital relations and specific character of personality's marital choice (O. Kliapets).

However, socio-psychological factors determining subjective well-being in marriage have not been the subject of a special socio-psychological investigation.

The aim of the paper is the analysis of the influence of socio-psychological factors on the formation of subjective well-being of a married person. The central task of the paper is to identify the structural components of subjective well-being of a married person, its functions and levels of manifestation.

\section{Methodology}

The research was carried out with the use of the following methods: questionnaire "Identifying the Specificity of Relations and Conditions for Interaction in Marriage" by Yu. Dmytruk; psychodiagnostic techniques: test "Checklist of Satisfaction with Marriage" (CSM) by V. Stolin, T. Romanova, H. Butenko; integrated technique "Diagnostics of Personality's Self-Fulfilment in a Family" (on the operational level, the level of values and role sets) modified by Yu. Dmytruk; semantical differential method by Ch. Osgud; "Oxford Happiness Questionnaire" (M. Argyle); techniques for diagnosing socio-psychological adaptation (SPA) (K. Rogers, R. Diamond adapted by O. Osnytskyi) and value orientations (M. Rokych); the scales of subjective well-being (G. Perrudet-Badoux adapted by M. Sokolova), social desirability (D. Crown, D. Marlow adapted by Yu. Khanin) and affective balance (N. Bredburn); questionnaires "Estimation of Correspondence between Family Values and Role Expectations in Marriage" (H. Volkova) and "Interpersonal Family Conflict” (IFC) by V. Levkovych, O. Zuskova. 


\section{Discussion}

The empirical study was conducted among 178 surveyed aged from 28 to 45 years who were married (89 married couples). The sample was composed according to the following criteria: "marital experience" (1-15 years), belonging to a certain social group (education, profession, financial situation, social reputation), parental status (number of children), etc. The sample participants were married couples, in which both partners agreed to take part in the research.

At the first stage of the empirical study, the sample was differentiated in terms of the participants' subjective well-being in marriage. The techniques were selected according to the criteria of subjective well-being that had been distinguished at the theoretical level (family's successful performance of its socio-psychological functions, satisfaction with marriage, the opportunity for selffulfilment in marriage). The analysis of the questionnaire, checklist of satisfaction with marriage and integrated technique of diagnostics of personality's self-fulfilment in a family (at the operational level and the level of values and role sets) with the use of frequency analysis has made it possible to divide the sample into two groups. The respondents whose marriage was subjectively successful $(40.4 \%)$ composed the first group characterised by the following indicators: $32-47$ points (according to CSM), $\geq 0.47$ points at the level of values and $\geq 4$ points at the level of abilities (according to Yu. Dmytruk), which corresponds to the medium and high level of their subjective well-being and satisfaction with marriage. The second group consisted of the respondents whose marriage was unsuccessful $(59.6 \%)$ and was characterised by the following parameters: $17-36$ points, $\leq 0.47$ points and $\leq 4$ points according to the corresponding techniques, which indicates subjective ill-being and the low level of satisfaction with marriage. It has been found that the quality of marital relations is assessed by means of subjective feelings of satisfaction with marriage that are sometimes different in a married couple. Wives from both groups feel less satisfied with marriage compared to their spouses regardless of well-being level in marriage. It demonstrates the fact that men feel more comfortable with their marital relations than women.

At the second stage, in order to distinguish sociopsychological factors of subjective well-being of a married person, the indicators of its major structural components' functioning (cognitive and evaluational, value and motivational, emotional and behavioural) in the distinguished groups, in particular according to gender distribution, were analysed.

In order to study cognitive and evaluational component, the respondents' vision of subjective well-being in marriage was analysed. As long as the image of subjective well-being has its categorical structure in the individual consciousness, it was identified by means of the semantical differential method that makes it possible to distinguish the following factors: rating, activity, strength, ordering, complexity, and comfort. As descriptors of sub- jective well-being, we distinguished the statements that were different in psychological content: family well-being, love, health, success, balance, satisfaction, confidence, tenderness, financial independence, harmony, etc. In this case, quantitative correlations of these associations in the first group $(\mathrm{Mo}=10.4)$ were significantly higher than in the second one $(\mathrm{Mo}=4.2)$. The results obtained by means of factor analysis made it possible to compare the categorical structure of the concept "subjective well-being" in both groups. In the first group, this parameter was characterised by higher rating, activity, strength, and complexity than in the second one $(\varphi=2.05 ; p \leq 0.02)$, where high rate of the factors of rating and complexity is combined with low rates of strength and activity factors, which demonstrates slight regulatory impact of the views about wellbeing with its high rating and cognitive complexity.

Analysis of the indicators demonstrating the respondents' assessment of satisfaction with present life, past and future, as well as authenticity and state of health (according to the scales of M. Argyle's techniques) has shown that the mean group rate of these parameters in the second group was statistically lower $(\mathrm{p} \leq 0.05)$. The evaluation of value and motivational component of subjective well-being has demonstrated that high rates according to all the scales of this technique in the first group indicate orientation at creative plans and engagement into the process of their implementation. Low rates in the second group demonstrate passive acceptance of life circumstances, which leads to discomfort, general dissatisfaction, and fatalism concerning marriage prospects $(\varphi=1.71 ; p \leq 0.04)$.

It has been found that in the system of a married couple's values there are both similarities and gender differences in their choice. For both men and women satisfaction with marriage is associated with the following values: happy family life (6.67 points; $\sigma=1.59)$, love (6.23 points; $\sigma=2.26)$, absence of financial difficulties (6.45 points; $\sigma=1.02)$, life wisdom (6.12 points; $\sigma=2.08$ ), shared leisure (7.43 points; $\sigma=1.56)$, demonstration of responsibility ( 7.31 points; $\sigma=1.22$ ). Gender differences were manifested in the fact that men considered the following values to be more important: independence (6.54 points; $\sigma=1.21$ ), self-control (5.58 points; $\sigma=3.07$ ), courage in defending one's opinion and views (6.61 points; $\sigma=2.44)$, inflexible will (6.15 points; $\sigma=3.62)$, openmindedness (5.29 points; $\sigma=2.98)$. Women considered other values to be important: orderliness, neatness and ability to keep one's things tidy (5.56 points; $\sigma=2.86$ ), good manners (5.07 points; $\sigma=2.88$ ), erudition (as breadth of knowledge and high general culture) (6.16 points; $\sigma=2.89)$, honesty (5.77 points; $\sigma=2.26)$, sensitivity and care (5.19 points; $\sigma=2.32$ ).

We have identified the correlation between the indicators of conformity of a married couple's values and their role-based adequateness in various spheres of family values. Conformity of a married couple's value sphere involves achieving cognitive similarity as well as conformity of their role behaviour. 
The results of dispersive analysis demonstrated the influence of conformity of a married couple's values in the sexual sphere, household and social activity on satisfaction with marriage. Gender differences were manifested in the fact that men showed more need for sexual and household relationships, while women needed personal identification with their husbands and parenthoodrelated relationships $(\mathrm{p} \leq 0.05)$.

There is a more expressed differentiation in the functioning of indicators of the emotional and behavioural component in both groups of the surveyed. The high level of subjective well-being is associated with the domination of positive emotional states, refusal of evaluating one's intrinsic merits according to formal achievements or others' estimations, high tolerance to frustration (let oneself and others make mistakes), which indicates regulatory function of the emotional and behavioural component in the first group $(\varphi=1.52 ; p \leq 0.06)$. Great significance of social environment, which was important for the members of the second group $(\varphi=1.66 ; p \leq 0.04)$, reduces the level of self-esteem, selfacceptance and self-respect, and prevents demonstrations of authenticity as an important mechanism of subjective wellbeing of a married person.

We have found that there is correlation between the high level of personality's subjective well-being in marriage and demonstration of socio-psychological adaptedness that was revealed in the first group $(\varphi=2.14$; $\mathrm{p} \leq 0.01)$. The indicators of the respondents' subjective well-being were such psychological makers as "internality", "self-acceptance" and "acceptance of others", which are frequently mentioned by married couples. In addition, "internality" dominates in women, and "self-acceptance" and "acceptance of others" dominates among men $(p \leq 0.01)$. Married couples from the first group are statistically different in terms of adaptedness, emotional comfort, low values of escapism, and stress accumulation $(\varphi=2.03 ; p \leq 0.02)$.

The results of dispersive analysis demonstrated the impact of the respondents' evaluation of the level of conflict proneness and emotional comfort on their satisfaction with marriage. The indicators of satisfaction with marriage and the level of conflict proneness in these spheres of marital interaction form one integrated index of subjective well-being, whose psychological content involves, first of all, person's emotional attitude towards his/her own marriage.

As for the influence of the respondents' evaluation of conflict proneness in the spheres of spouses' communication and communication culture (according to IFC) on subjective well-being of a married person, the results obtained confirm the fact that communication difficulties remain one of the main causes of conflicts between spouses in a contemporary family.

The data of objective techniques were supplemented by the data of the questionnaire intended for identifying the impact of socio-economic and demographic characteristics of the groups under study on experiencing subjective well-being in marriage. There were no significant differences between families with and without children in terms of the indicators of family role interaction, evaluation of conflict proneness level, peculiarities of family communication, and satisfaction with marriage. Therefore, subjective well-being does not depend directly on parental status or sibship size. The author has also found that living conditions are considered as an objective factor that affects a married couple's subjective evaluation of satisfaction with their everyday life and experiencing subjective well-being in marriage. Satisfaction with financial situation in a family, order in family's household create favourable conditions for the high level of satisfaction with marriage and personality's experiencing subjective well-being in general. In terms of gender differences, we have identified that men with higher level of education find emotional support of their wives more significant. Women from the families where spouses have the same educational level or wife's educational level is higher give priority to the solidarity of a married couple's value orientations. There were some differences in experiencing subjective well-being depending on the period of being married. According to the questionnaire, within prospective adaptation period (1-5 years of living as a couple), participants of the first group consider moral and psychological relationships to be the principal factor of well-being. At the same time, participants of the same group with more experience of living as a couple consider their well-being to be dependent on family and parental relationships. Understanding, care and respect were important for all the couples.

To conduct factor analysis aimed at comparing the factors affecting subjective well-being of a married person using the visual method, we analysed the data of diametrically opposed manifestations of the indicators of subjective well-being components in both groups.

General analysis of the factor matrix made it possible to identify the descriptors ("adaptedness vector", "personal growth vector", "vector of psychological well-being in marriage", "vector of marital and role interaction") that enabled us to distinguish socio-psychological factors of personality's well-being in marriage: socio-psychological adaptedness and tolerance, satisfaction with marriage; conformity of the level of family values significance in emotional, sexual, household, parental spheres and social activity sphere; orientation at and opportunities for selfdevelopment, self-improvement and personal achievements combined with dominating family values; determination and conformity of role expectations and role intentions; similar visions of role behaviour; low level of conflict proneness in family interaction (marital support, emotional comfort, communication culture).

\section{Conclusions}

Thus, personality's subjective well-being in marriage is multifunctional integral socio-psychological formation that includes cognitive and evaluational (specification and extension of knowledge about oneself, views of subjective wellbeing in marriage, personal assessment of reality, attitude to oneself and the spouse), value and motivational (develop- 
ment of positive attitude to oneself, reasonable estimate of one's capabilities and capacity in family life as well as personal growth in marriage, identification of prospects for ones' future in it and implementation of life goals), emotional and behavioural (the level of emotional perception of spouses' interaction, the degree of satisfaction with marriage and control over its circumstances, social demand) components. Principal functions of subjective well-being are regulatory, forecasting, and developmental one. The levels of manifestation of personality's subjective well-being in marriage (material, personal, social, physical, psychological) correspond to value orientation types and personality's motivational structure and are enunciated depending on the present life situation in marriage.

The authors have identified socio-psychological factors of personality's subjective well-being in marriage: socio-psychological adaptedness and tolerance; similar

\section{REFERENCES}

1. Abulkhanova, K. A., Berezina, T. N. (2001). Vremya lichnosti $i$ vremya zhizni [Time of a personality and time of life]. St. Petersburg: Aleteyya [in Russian].

2. Kireyeva, Z. A. (2013). Razvitie lichnosti v ramkakh prostranstvenno-vremennoy organizatsii zhiznennogo puti [Development of a personality in terms spatial and temporal organisation of course of life]. Visnyk $O N U$ im. I. I. Mechnikova. Psikhologiya - Bulletin of I. I. Mechnikov Odessa National University. Psychology, 18, 68-73 [in Ukrainian].

3. Cherneta, S. (2015). Sotsialna aktyvnist osobystosti yak umova rozvytku suchasnoho ukrayinskoho suspilstva [Social activity as the condition for development of contemporary Ukrainian society]. Naukovyi vis-

\section{ЛІТЕРАТУРА}

1. Абульханова К. А. Время личности и время жизни / К. А. Абульханова, Т. Н. Березина. - СПб. : Алетейя, 2001. - 304 с.

2. Киреева 3. А. Развитие личности в рамках пространственно-временной организации жизненного пути / 3. А. Киреева // Вісник ОНУ ім. І. І. Мечникова. Психологія. - 2013. - Т. 18. - Вип. 22. - Ч. 2. - С. 68-73.

3. Чернета С. Соціальна активність особистості як умова розвитку сучасного українського суспільства / С. Чернета // Науковий вісник Східноєвропейського value orientations with the partner and happy marital relations; satisfaction with marriage; conformity of the level of family values significance in emotional, sexual, household, parental spheres, the sphere of personal identification and social activity; opportunity for selfdevelopment, self-improvement and personal achievements combined with dominating family values; determination and conformity of role expectations and role intentions; similar views of role behaviour; low level of conflict proneness in family interaction (marital support, emotional comfort, communication culture).

The study of the peculiarities of experiencing subjective well-being among married people of different ages and according to gender differences as wel as at different stages of family's life cycle requires further consideration.

nyk Skhidnoievropeiskoho natsionalnoho universytetu im. Lesi Ukrayinky. Pedahohichni nauky - Scientific bulletin of Lesya Ukrainka East European National University. Pedagogy, 1, 177-180 [in Ukrainian].

4. Titarenko, T. M. (Ed.). (1998). Psykholohiia zhittievoi kryzy [Psychology of vital crisis]. Kyiv: Agropromvidav Ukrainy [in Ukrainian]

5. Chebykin, O. Ya., \& Pavlova, I. H. (2009). Stanovlennia emotsiinoi zrilosti osobystosti [The development of personality's emotional maturity]. Odesa: SVD Cherkasov [in Ukrainian].

6. Maksymenko, S. D. (2015). Genesis of personality existence. Montreal: Accent Graphics Communication [in English].

національного університету ім. Лесі Українки. Педагогічні науки. - 2015. - № 1. - С. 177-180.

4. Психологія життєвої кризи / Відп. ред. Т. М. Титаренко. - К. : Агропромвидав України, 1998. - 348 с.

5. Чебикін О. Я. Становлення емоційної зрілості особистості : [монографія] / О. Я. Чебикін, І. Г. Павлова. - Південний науковий центр АПН України. Одеса : СВД Черкасов, 2009. - 232 с.

6. Maksymenko S. D. Genesis of personality existence / S. D. Maksymenko. - Montreal : Accent Graphics Communication, 2015.

Юрій Анатолійович Завацький, кандидат психологічних наук, завідувач кафедри здоров'я людини та фізичного виховання,

Східноукраӥнський національний університет імені В. Даля, просп. Центральний, 59А, м. Сєвєродонеиьк, Украӥна

\section{ВПЛИВ СОЦІАЬНО-ПСИХОЛОГІЧНИХ ЧИННИКІВ НА ФОРМУВАННЯ СУБ’ЄКТИВНОГО БЛАГОПОЛУЧЧЯ ОСОБИСТОСТІ В ШЛЮБІ}

У роботі розглянуто актуальність вивчення проблеми суб'єктивного благополуччя особистості в шлюбі в умовах трансформаційних змін усіх сфер життя сучасного суспільства. Метою дослідження є аналіз впливу соціально-психологічних чинників на формування суб'єктивного благополуччя особистості в шлюбі. Основним 
завданням наукового пошуку є визначення структурних складових суб'єктивного благополуччя особистості в шлюбі, його функцій і рівнів прояву. Дослідження проводилося на основі анкетування, психодіагностичних методик вивчення задоволеності шлюбом, самореалізації особистості в сім'ї (на операціональному рівні та рівні цінностей і рольових установок), соціально-психологічної адаптованості, узгодженості сімейних цінностей i рольових очікувань в шлюбі. Показано, що суб'єктивне благополуччя особистості в шлюбі - це поліфункціональне інтегральне соціально-психологічне утворення, в структуру якого входять когнітивно-оцінна, мотиваційно-ціннісна, емоційно-поведінкова складові. Встановлено, що провідними функціями суб'єктивного благополуччя є регулятивна, прогностична та розвиваюча. Виділено соціально-психологічні фактори суб'єктивного благополуччя особистості в шлюбі: соціально-психологічна адаптованість і толерантність; ціннісноорієнтаційна єдність 3 партнером і благополуччя шлюбних відносин; задоволеність шлюбом; узгодженість ступенем значущості сімейних цінностей в емоційній, інтимно-сексуальній, господарсько-побутовій, батьківськовиховній сферах, сферах особистісної ідентифікації та соціальної активності; можливість саморозвитку, самовдосконалення і особистих досягнень в поєднанні з домінуванням сімейних цінностей; визначеність і несуперечливість рольових очікувань і рольових домагань, збіг уявлень про рольову поведінку; низький рівень конфліктності у взаємодії подружжя (підтримка, емоційний комфорт, культура спілкування). Основним напрямком подальших досліджень розглядається вивчення особливостей переживання суб'єктивного благополуччя в шлюбі на різних етапах проходження стадій життєвого циклу сім'ї.

Ключові слова: особистість, благополуччя, шлюб, соціально-психологічні чинники, суб’єктивне благополуччя.

Submitted on January, 10, 2017

Reviewed by Doctor of Psychology, prof. M. Toba

UDC: 159.922 .7

DOI: https://doi.org/10.24195/2414-4665-2017-1-2

Nataliia Volianiuk,
Doctor of Psychology, professor,
Head of the Department of Psychology and Pedagogy,

Olha Bokovets, post-graduate student, Department Psychology and Pedagogy, National Technical University of Ukraine "Igor Sikorsky Kyiv Polytechnic Institute", 37, Peremogy Avenue, Kyiv, Ukraine

\section{PSYCHOLOGICAL STRUCTURE OF INNOVATIVE POTENTIAL OF A PERSONALITY}

The article is devoted to the theoretical substantiation of the psychological structure of the innovative potential of a personality. The concept of the "innovative potential of a personality" is reviewed from the perspective of two phenomena, namely "innovation" and "potential". The innovation is considered as a result of innovative activity, which includes creation, development and use of the new. The potential is conceived as a system of opportunities, productive forces, reserves and resources, the extent of which, hypothetically, to a greater extent depends on the personality, and to a lesser extent - on external factors. The innovative potential is a dynamic integrated set of social and psychological characteristics of a personality that determines his/her capacity for creation, development and use of the new, and as a result of its implementation it will fulfill the needs of the society and will produce further socialized development of a personality. The following structural components of the innovative potential of a personality are highlighted: "environmental" (social, material and spiritual) and personal (motivational and value, cognitive, creative, emotional and volitional, and regulatory) resources.

Keywords: innovation, potential, resource, personality, structure.

\section{Introduction}

Modern society is often called the society of knowledge-based economy driven by knowledge, which is concentrated in human capital assets. At the same time, the ability to generate, use and distribute new knowledge determines the creation of highly qualified services and products, thereby ensuring the growth and competitiveness of such economy on the international scene. Consequently, there occurs a gradual transition to the innovative development of society driven by the innovative personality who has the knowledge of current importance, flexibility and critical thinking, creativity and high adaptive abili- 